\title{
APPLICATION OF HOUSE OF QUALITY IN THE CONCEPTUAL DESIGN OF BATIK WAX EXTRUDER AND PRINTER
}

\author{
Nurul Anissa Mohd Asti ${ }^{1}$, Abdul Malek Abdul Hamid ${ }^{1}$, Norhashimah \\ SHAFFIAR ${ }^{1}$, NOR AIMAN SUKINDAR ${ }^{1}$, SHARIFAH IMIHEZRI SYED \\ SHAHARUDDIN ${ }^{1 *}$ AND FARID SYAZWAN HASSAN ${ }^{2}$ \\ ${ }^{I}$ Department of Manufacturing and Materials Engineering, Kulliyyah of Engineering, \\ International Islamic University Malaysia, \\ Jalan Gombak, 53100 Kuala Lumpur, Malaysia \\ ${ }^{2} 3 D$ Gens Sdn Bhd, Bukit Jelutong, 40150 Shah Alam, Malaysia \\ *Corresponding author: shaimihezri@iium.edu.my
}

(Received: $12^{\text {th }}$ February 2021; Accepted: $10^{\text {th }}$ June 2021; Published on-line: $4^{\text {th }}$ January 2022)

ABSTRACT: Malaysian batik production is dominated by two techniques known as hand-drawn batik, or batik tjanting, and stamp batik, or batik block. In comparison to batik block, the more popular batik tjanting takes a longer time to produce. A Standardized Nordic Questionnaire (SNQ) for musculoskeletal symptom examination involving batik artisans in Kelantan and Terengganu identified high rates of musculoskeletal disorders in respondents due to their working posture during the batik tjanting process. It was also observed that the number of workers and artisans willing to participate in the traditional batik industry is on the decline. These problems have led to a systematic Quality Functional Deployment approach to facilitate the decision-making process for the conceptual design of an automatic batik printer. In this study, house of quality (HOQ) was applied to identify the critical features for a batik printer based on the voice of the customer (VOC). A survey done to rate the importance of VOC using an 8-point Likert scale revealed that the batik practitioners topmost priority for the batik printer feature is the 'ability to adjust and maintain the temperature of wax' (17.54\%) while the non-batik practitioners chose 'ability to deliver a variety of complex designs' (15.94\%). The least required feature for the batik printer was related to the size of the batik printer. The mapping between customer requirements (VOC) and technical requirements identified that the extruder design (21.3\%), the heating element (18\%), and nozzle diameter $(17.8 \%)$ were the most critical components for the batik printer. Several conceptual designs of the extrusion unit, cartesian-based batik printer, and 2D image conversion using open-sourced software were proposed at the end of this work.

ABSTRAK: Pengeluaran batik Malaysia telah didominasi oleh dua teknik yang dikenali sebagai batik lukisan-tangan (batik canting) dan batik cap (batik blok). Sebagai perbandingan, batik canting yang popular mengambil masa lebih lama bagi dihasilkan. Soal Selidik Nordic Standad (SNQ) bagi meneliti gejala muskuloskeletal melibatkan tukang batik di Kelantan dan Terengganu telah menunjukkan persamaan kadar muskuloskeletal yang tinggi pada postur badan semasa bekerja canting batik. Bilangan pekerja yang terlibat dalam industri tradisional batik ini turut terjejas. Masalah-masalah ini telah mengarah kepada kaedah Pengerahan Fungsi Kualiti bagi membantu proses membuat keputusan dalam rekaan konsep pencetak batik automatik. Kajian ini telah mengadaptasi Kualiti Rumah (HOQ) bagi mengesan ciri-ciri kritikal pada pencetak batik berdasarkan suara pelanggan (VOC). Kaji selidik telah dilakukan bagi menilai kepentingan VOC menggunakan skala Likert 8-poin. Didapati keutamaan yang diperlukan 
oleh $17.54 \%$ ahli batik adalah; ciri pencetak batik ini perlu mempunyai 'keupayaan dalam menyelaras dan menetapkan suhu lilin', manakala sebanyak $15.94 \%$ bukan ahli batik memilih 'keupayaan pencetak ini harus berjaya menghasilkan pelbagai rekaan yang kompleks'. Ciri yang kurang diberi tumpuan adalah berkaitan saiz pencetak batik. Persamaan antara kehendak pelanggan (VOC) dan kehendak teknikal dalam mengenal pasti komponen-komponen penting bagi pencetak batik adalah rekaan penyemperit (21.3\%), elemen pemanas (18\%), dan diameter nozel (17.8\%). Pelbagai rekaan konsep bagi unit penyemperit, pencetak batik canting, dan imej konversi 2D menggunakan perisian sumber terbuka telah dicadangkan di bahagian akhir kajian ini.

KEYWORDS: batik; house of quality (HOQ); conceptual design; extruder; batik printer

\section{INTRODUCTION}

The establishment of the Rural and Industrial Development Authority (RIDA) in 1951 marked the Malaysian government's formal initiative to develop the handicraft industry as part of rebuilding the rural community's economy and society. In the Fourth Malaysia Plan (1981-1984), handicraft activity was given due recognition as an 'industry sector' that required revitalization to aid in the eradication of rural poverty. The initiated rural urbanization strategy was extended in the 'Halacara Baru' (New Direction) program in 1984, which led to significant progress in the handicraft industry [1]. This scenario granted an opportunity for the batik industry to reap the benefits from the larger economic movement and became a major contributor to the overall sales of the handicraft industry [2]. The production of batik in Malaysia is dominated by two techniques: hand-drawn batik, also known as batik tjanting, and stamp batik, or batik block. In comparison to batik block, batik tjanting allows for greater freedom in design, has a longer production time, and is sold at a higher price.

Tjanting is a tool designed with a small container head made from copper with a spouted end that is attached to a wooden handle, as shown in Fig. 1. The copper head acts as a reservoir that supplies molten wax to a copper spout. The main problem in using tjanting in the waxing process arises from the lack of thermal control of the molten wax which then affects the quality of the wax lines drawn on the fabric [3]. The initial wax lines drawn on the fabric tend to be thick and as the wax in the copper container gradually cools down, the wax's increase in melt viscosity causes the rendered wax line to become thinner, unsmooth, and penetrates less into the fabric.

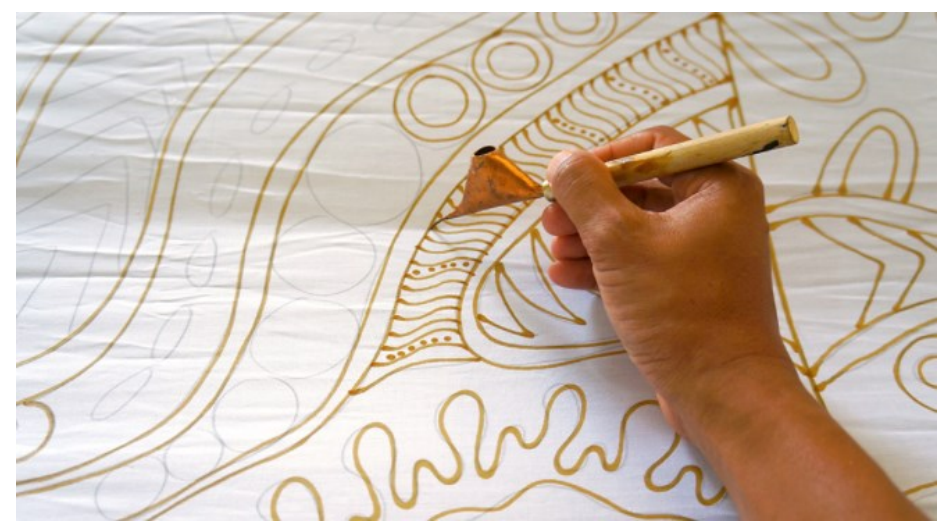

Fig. 1: The batik artisan holds the tjanting tool at an angle whilst rendering the batik wax on the fabric [4]. 
A body map adapted from a Standardized Nordic Questionnaire (SNQ) for musculoskeletal symptom examination was used to evaluate work-related musculoskeletal symptoms amongst batik tjanting workers in Kelantan and Terengganu [5,6]. Musa et. al [5] observed that postural movement of the batik workers includes standing for more than four hours, continuous hand/wrist movements as well as bending/stooping. While Yusof et al. [6] noted that the majority of the batik workers did not get enough rest during the tjanting phase. These working postures and long-standing hours have led to work-related musculoskeletal disorder (MSD) symptoms amongst batik workers. A study on batik workers in Kelantan revealed the feeling of discomfort occurred mostly at the shoulders (41.0\%), lower back (34.4\%), and ankles or feet (34.4\%) whilst Terengganu batik workers revealed that discomfort was frequently felt at the shoulders $(64.5 \%)$, sole $(61.3 \%)$, upper back (51.6\%), hand (51.6\%), legs (51.6\%), knee (48.4\%) and wrist (45.2\%).

Several automatic batik printing systems such as the Integrated Computer-Aided Tjanting system (ICATS)[7] and the batik Kelowong Machine [8] have been developed. An automated Batik Colouring System [9] had also been built to achieve a similar coloring effect and aesthetic as hand-coloring. However, the application of these automated batik systems has been lacking in the local batik communities. According to Affanti and Hidayat [10], the acceptance of any new form of batik tool is influenced by the batik craftsmen's requirements such as comfort and efficiency. Hence, it is necessary to systematically identify end-user requirements and market segments to increase new batik tools' performance and values. A literature search revealed that the end-user requirements for batik printers have never been systematically investigated qualitatively and quantitatively for the Malaysian market. Table 1 summarizes the possible attributes for a batik printer model based on numerous studies which include printing speed, printing quality, operation, temperature, and cost.

Table 1: Attributes of a batik printer

\begin{tabular}{ccc}
\hline & Batik printer features & References \\
\hline $\begin{array}{c}\text { Printing speed } \\
\text { Printing quality }\end{array}$ & $\begin{array}{c}\text { Ability to produce batik at a high production rate. } \\
\text { Consistency in wax line thickness and quality } \\
\text { Consistency in drawing repeated and complex } \\
\text { design }\end{array}$ & {$[11]$} \\
Operation & Minimum fabrication skill & {$[3,11,12]$} \\
& Ease of use & {$[11,13]$} \\
Temperature & Ability to adjust the temperature of the wax & {$[8,12]$} \\
Cost & Low cost & {$[12,14]$} \\
& &
\end{tabular}

Commonly used tools to obtain inputs from end-users or stakeholders in the design process include Pugh method (PM), decision matrix (DM), quality function deployment (QFD), and analytical hierarchy process (AHP)[15]. QFD was developed more than 25 years ago in Japan and is used in product planning, design deployment, process planning, and production planning of newly designed products. QFD can be used to transform customer requirements into technical design parameters, to compare the product's strengths and weaknesses with available competitors' products, to improve product performance, and to offer shorter product development time at an effective cost $[17,18]$. One of the vital components in QFD is the house of quality (HOQ), a cross-functional tool that embeds consumer preferences in the new product design specification [18]. Both PM and DM 
approaches identify the relative ranking among design alternatives based on weighted attributes $[21,22]$. In comparison to PM and DM, the HOQ approach enables proper identification and relative ranking of the product's technical requirements that need to be urgently improved, hence, the product can be developed in a targeted or focused manner to achieve customer satisfaction [21]. The method also does not require a very large number of comparisons to make a decision, as seen in AHP [22]. QFD and HOQ have been deployed to design and improve various batik-related products such as batik coloring machines [23], batik designs [24], batik merchandise [27,28], and natural batik dies [27].

This study intends to identify the critical features of a batik printer according to the customer or end-user requirements, employs HOQ to aid in the decision-making process, and proposes a conceptual design for a customer-based batik printer. The outcome of this study can be used to increase the market value of the batik printer and promotes the growth of the batik industry.

\section{METHODOLOGY}

The overall process flow used to derive the conceptual design is shown in Fig. 2. The process flow starts with determining the market survey and ends with the conceptual design of the most critical component based on engineering specifications.

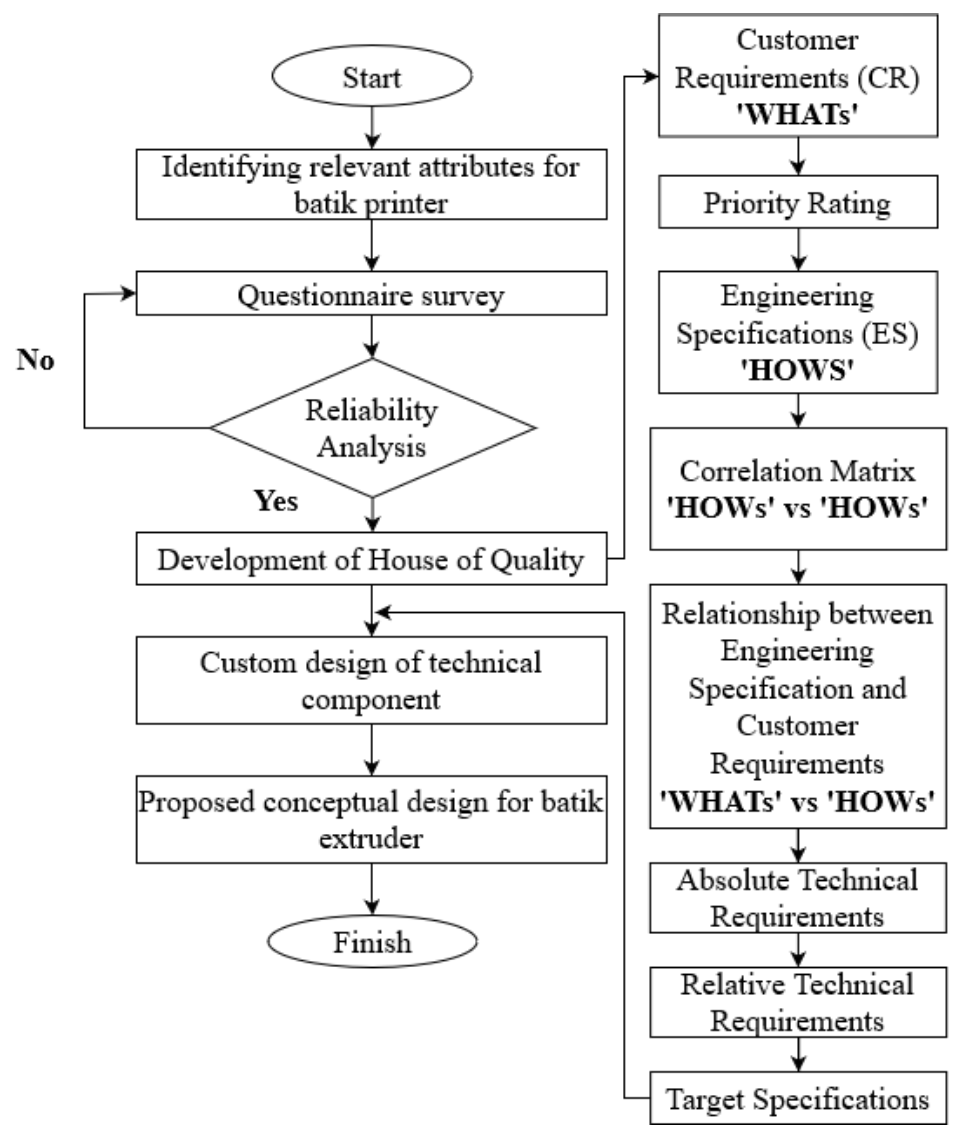

Fig. 2: Overall process flow used to develop the conceptual design of batik printer.

\subsection{Questionnaire Survey}

A quantitative method via questionnaire was designed based on batik printer features including printing speed, ability to adjust and maintain the temperature of the wax, ease of operation, ability to maintain consistency of wax line thickness and quality, ability to deliver 
a variety of complex design, cost of equipment, size of equipment and maintenance (refer to Table 2). The survey aims to identify the rating of importance of these printer features on a Likert scale of 1-8. Questionnaires were administered via Google form as well as manual handout. The sample population for the survey was determined based on Eq. (1) due to the unknown number of customers.

$$
n=\frac{P(1-P) Z^{2}}{d^{2}}
$$

where $\mathrm{n}=$ size of sample

$\mathrm{P}=$ standard deviation/ expected proportion at $30 \%=0.3$

$\mathrm{Z}=$ normal random variables $=(1.645)$

$\mathrm{d}=$ margin of error in estimating $\mathrm{P}[28]=(0.05)$

Equation 1 proposes that at $90 \%$ of the confidence interval [29] the total number of participants in the survey should be at least 227 . In this study, the survey received was compiled based on a total of 241 respondents and the demographic of the respondents is shown in Table 3.

Table 2: Questionnaire developed based on the required attributes of a batik printer

\begin{tabular}{|c|c|c|c|c|c|c|c|c|c|}
\hline \multicolumn{10}{|c|}{$\begin{array}{c}\text { Note: Kindly rank in terms of importance for each printer feature according to } 1 \text { (least preferred) } \\
\text { to } 8 \text { (highly preferred). }\end{array}$} \\
\hline \multirow[t]{2}{*}{ Table 1 attributes } & \multirow[t]{2}{*}{ Questionnaire attributes } & \multicolumn{8}{|c|}{$\begin{array}{l}\text { Scale } \\
\end{array}$} \\
\hline & & 1 & 2 & 3 & 4 & 5 & 6 & 7 & 8 \\
\hline Printing speed & Printing speed & & & & & & & & \\
\hline Temperature & $\begin{array}{l}\text { Ability to adjust and maintain the } \\
\text { temperature of the wax }\end{array}$ & & & & & & & & \\
\hline Operation & Ease of operation & & & & & & & & \\
\hline \multirow[t]{2}{*}{ Printing quality } & $\begin{array}{l}\text { Ability to maintain consistency of wax } \\
\text { line thickness and quality }\end{array}$ & & & & & & & & \\
\hline & $\begin{array}{l}\text { Ability to deliver a variety of complex } \\
\text { design }\end{array}$ & & & & & & & & \\
\hline Cost & Cost of equipment & & & & & & & & \\
\hline \multirow[t]{2}{*}{ Operation } & Size of equipment & & & & & & & & \\
\hline & Maintenance & & & & & & & & \\
\hline
\end{tabular}

Table 3: Demographics of the survey population

\begin{tabular}{cccc}
\hline \multicolumn{2}{c}{ Profession } & \multicolumn{2}{c}{ Frequency } \\
\hline \multicolumn{2}{c}{ Batik Practitioner } & \multicolumn{2}{c}{64} \\
\multicolumn{2}{c}{ Non-batik Practitioner } & \multicolumn{2}{c}{177} \\
\hline \multicolumn{2}{c}{ Batik practitioner } & \multicolumn{2}{c}{ Non-batik practitioner } \\
Gender & Frequency & Gender & Frequency \\
\hline Female & 52 & Female & 130 \\
Male & 12 & Male & 47 \\
\hline Age (years) & Frequency & Age (years) & Frequency \\
\hline $20-30$ & 44 & $20-30$ & 118 \\
$31-40$ & 13 & $31-40$ & 24 \\
$41-50$ & 5 & $41-50$ & 32 \\
$51-60$ & 2 & $51-60$ & 3 \\
\hline
\end{tabular}




\subsection{Reliability Analysis}

Cronbach alpha is an important concept for the evaluation of assessment and questionnaires [30]. The reliability of the measurements was assessed by computing Cronbach's alpha by using IBM SPSS Statistics 26.0 to analyze the statistics.

\subsection{House of Quality}

The design structure for HOQ is very flexible and contains the same basic building components shown in Fig. 3 below. In this study, the features for the HOQ are depicted in Fig. 4 and involve input from a focus group with relevant experience in the development of a $3 \mathrm{D}$ printer from the university and industry. The description of each process for each room to design the batik printer features is explained below.

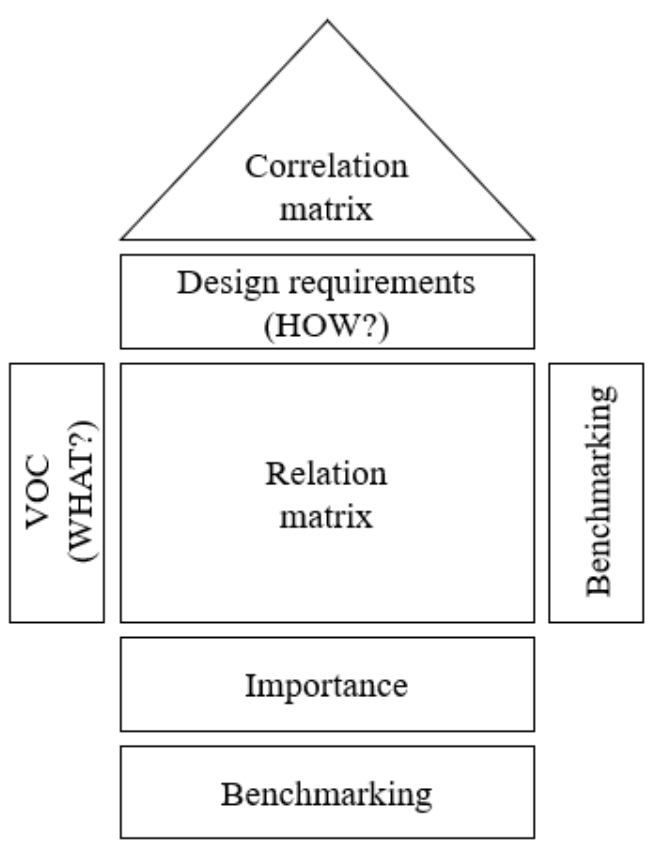

Fig. 3: Basic building structure for HOQ [31].

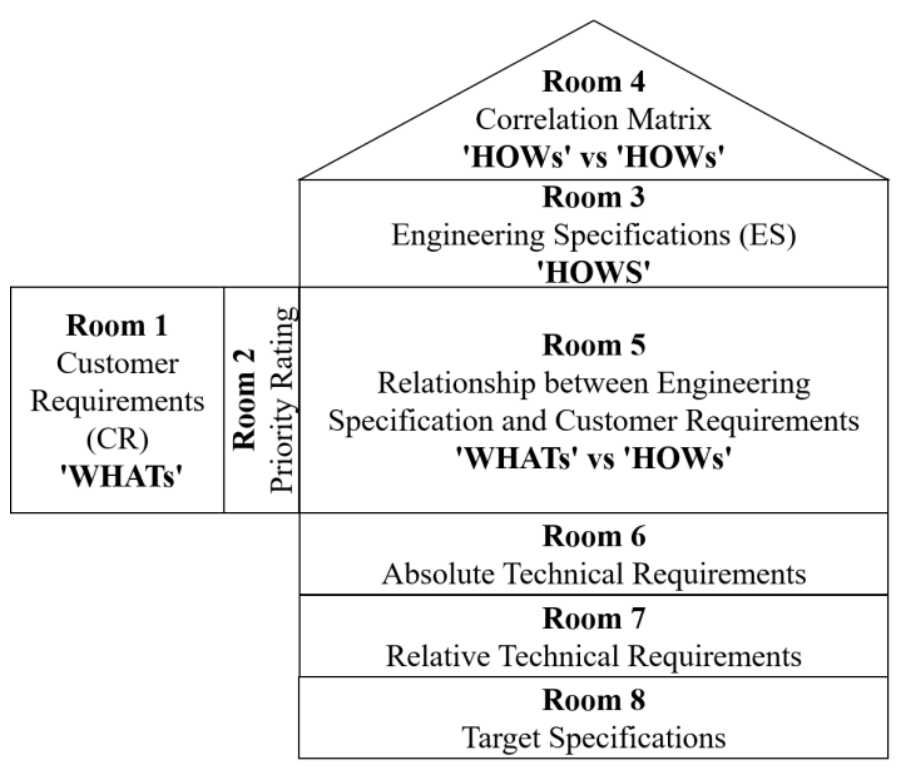

Fig. 4: Adapted HOQ matrix for the conceptual design of the batik printer. 
a. Room 1: Customer requirements (CR).

The characteristics of product features and functions are not necessarily the same for the designers as for the customers. The customer requirements ('WHATs') represent the voice of customers (VOC) for the batik printer features and were determined based on bibliographic and literature searches [32]. These features are summarized in Table 2 and are used to develop the questionnaire for the market survey.

b. Room 2: Customer requirement priority rating.

The priority rating for customer requirements can be deliberated via the team's direct experience with the customer or determined based on a survey [33]. In this study, each CR is prioritized by assigning a numeric value called the degree of importance on a scale of 1-8 based on a market survey.

c. Room 3: Engineering specifications (ES).

Engineering specification (How's) represents the product requirements in measurable technical terms. In this study, ES is the result of brainstorming sessions with a focus group consisting of industry experts in 3D printing, 3D Gens SDN BHD, and the additive manufacturing unit at the International Islamic University Malaysia (IIUM).

d. Room 4: Correlation matrix.

The matrix of correlation illustrates the relationship between the features of engineering ('How vs. How'). The intensity of the correlation is provided by symbols that imply positive or negative interaction while other features remain unchanged. The double-positive symbol $(++)$ implies a strong positive correlation, $(+)$ a positive correlation, (--) a strong negative correlation, and (-) a negative correlation. This allows a better understanding of the relationship of various ES and negates any contradictions and unnecessary increases in cost. The correlation was evaluated by the researcher and experts [34] from the addictive manufacturing focus group at IIUM.

e. Room 5: Relationship between customer requirements (CR) and engineering specifications (ES).

The main relationship between customer requirements and engineering specifications ('What vs How') was determined as shown in the product architecture in Fig. 5. The relationship matrix was then developed to include a list of how the engineering specifications serve the needs of each customer using a commonly employed 1-3-9 scale [35]. Rating scale 1 is a minor or potential relationship, 3 is a moderate relationship, and 9 is a solid relationship. The evaluation was assisted by the researcher and experts $[38,36]$ from the additive manufacturing focus group at IIUM and 2D printer from the industry as it requires technical insight and understanding of the relationship between CR and ES.

f. Room 6: Absolute technical requirements 
The importance of the significance level of the absolute technical requirement (SL_ABS) reflects the engineering specifications required to satisfy the customer's requirements and can be determined using Eq. 2 [29].

$$
\begin{aligned}
& \text { SL_ABS }=\sum \text { (value of relationship between customer requirements and } \\
& \text { engineering specifications } \mathrm{x} \text { important ranking value) }
\end{aligned}
$$

g. Room 7: Relative technical requirements

The value of the significance level of the relative technical requirements (SL_REL) can be evaluated as follows in Eq. 3 [29].

$$
\mathrm{SL}_{-} \mathrm{REL}=\underline{\text { (significance level of absolute technical requirements }) \times 100}
$$

The absolute and relative technical requirements are used to rank the engineering specification (ES). The priority list of ES enables the designer/manufacturer to optimize the product design.

h. Room 8: Target specification

Target specification represents objectives for product design or improvement. They summarize the basic data that reflect the customer requirements and can be used to identify strategic design opportunities.

\subsection{Conceptual Design for the Batik Extruder and Printer}

The main component for the conceptual design of the batik printer was prioritized based on the ranking obtained in ES and CR. A systematic exploration was adopted using a combination table that integrates the relative technical attributes and the printing features based on the result of the HOQ. Autodesk Fusion 360 is used to generate the conceptual designs of the extruder and the overall framework of the batik printer.

\section{RESULTS AND DISCUSSION}

\subsection{Questionnaire Survey}

Cronbach's analysis provides a measure of the internal consistency of a test or scale, expressed as a number between 0 to 1 . The acceptable values of alpha range from 0.70 to 0.90 . The result for alpha in this study is 0.948 , therefore the reliability analysis on a questionnaire survey of 241 respondents is confirmed.

The batik printer features used in the survey correlate to the customer requirements (CR) or the voice of customers (VOC) in the HOQ matrix. The respondent demographics can be divided into two types. In this study, batik practitioners are clarified as respondents who have theoretical and practical knowledge of batik production and are directly involved in the batik making lifecycle either in the design, production, and distribution of batik fabrics. In contrast, non-batik practitioners refer to respondents that do not have theoretical knowledge of batik production, lack experiential and practical knowledge, and are not directly involved in the batik production life cycle. The survey data presented in Fig. 6(a) and Fig. 6(b) demonstrates that the distribution of preferences for printer features differs in ranking between the batik practitioners and non-batik practitioners. It was found that $17.54 \%$ of the batik practitioners agreed that the most important feature for the batik printer is the ability to 'adjust and maintain the temperature of the wax' whilst $15.94 \%$ of the nonbatik practitioners prioritized the 'ability to deliver a variety of complex designs' attribute. 
Both groups deliberated that the 'size of the equipment' attribute is of the least importance. The distribution of percentage for each feature for the batik printer was translated into the priority rating in Table 4 . It is proposed that the high priority rating of the batik practitioners for a batik printer that can adjust and maintain its wax temperature is attributed to the experiential or practical exposure to wax rendering activity using tjanting. The traditional tjanting is not equipped with isothermal control of the wax melt which leads to inconsistent quality and variation in wax line thickness rendered on the fabric. Previously, the traditional tjanting tool was innovated by incorporating an electrical heating system [10,39]. However, the improved version did not take off amongst batik artisans due to ergonomic issues and insufficient exposure to the tool's operation and performance [10].

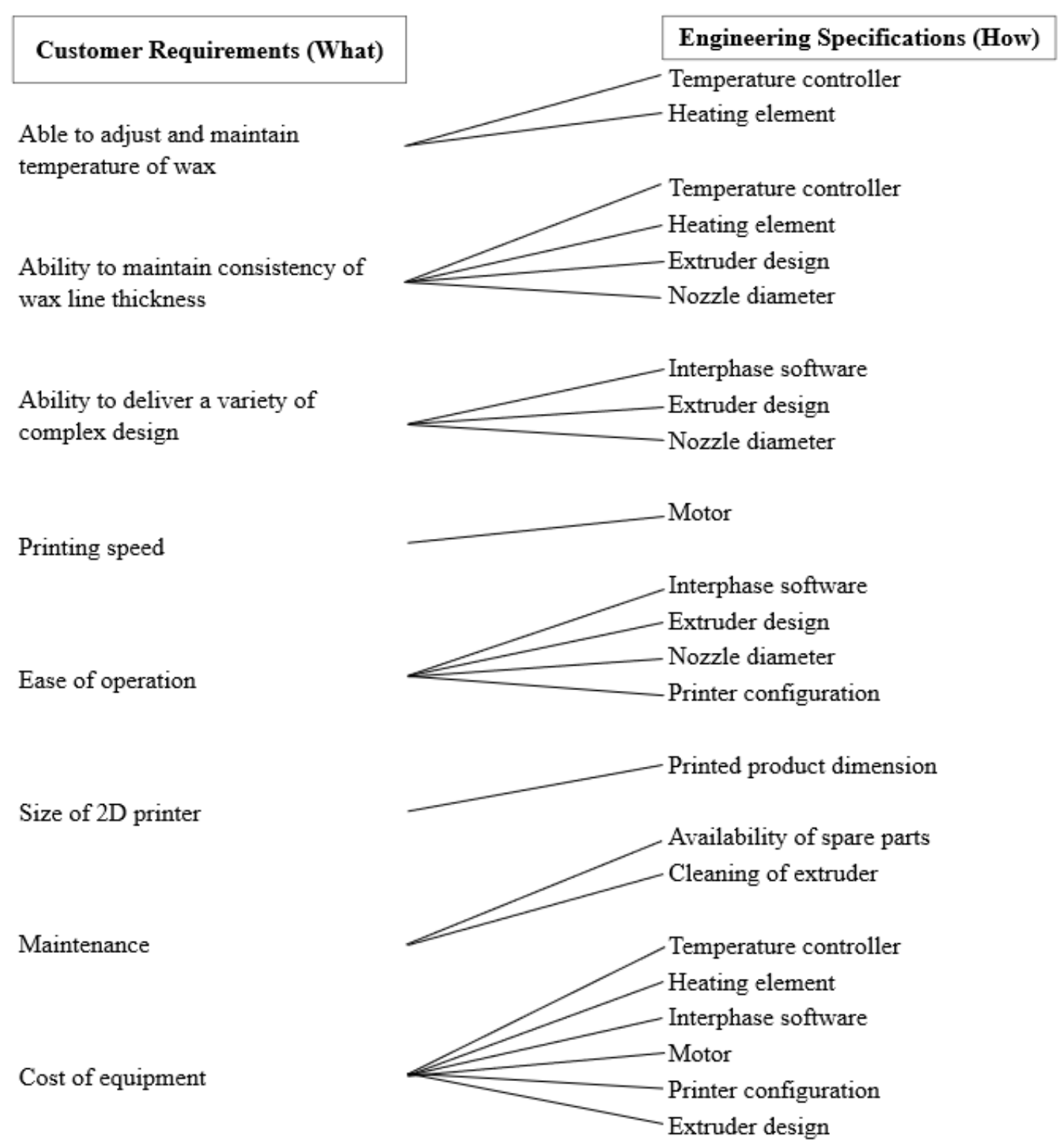

Fig. 5: Main correlation between engineering specification (How) and customer requirements (What) for the batik printer. 
a)

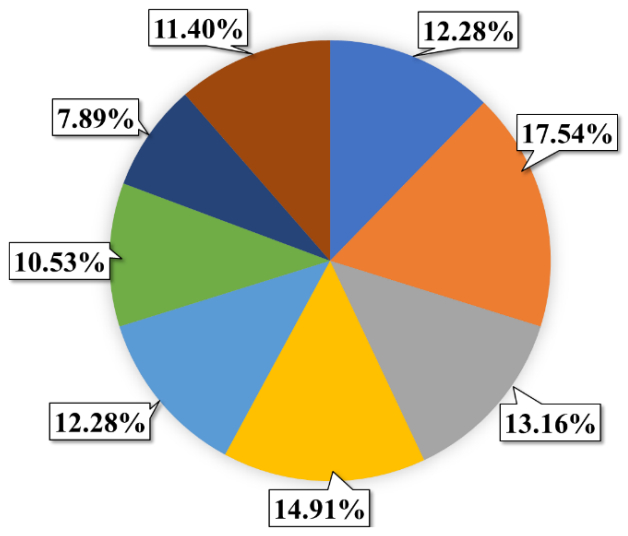

b)

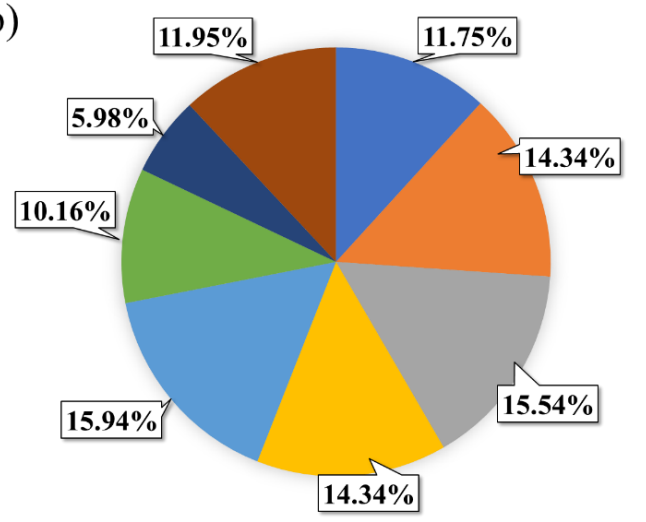

Printing speed

Able to adjust and maintain temperature of wax

Ease of operation

Ability to maintain consistency of wax line thickness

- Ability to deliver a variety of complex design

- Cost of equipment

- Size of $2 \mathrm{D}$ printer

- Maintenance

Fig. 6: The distribution of preferences for the batik printer attributes for (a) batik practitioners and (b) non-batik practitioners.

The non-batik practitioner's high preference for a batik printer that is capable to deliver a variety of complex designs is consistent with the local's aesthetic appreciation towards batik products. Poon's [38] study on determinant factors for the demand in batik products identified that design is the most crucial element followed by quality and price. The apparent differences in the ranking of priorities prove that human perception in prioritizing product attributes can be vague [39] due to personal taste and usage [40].

Table 4: The batik practitioners and non-batik practitioner's priority ratings of batik printer features based on survey.

\begin{tabular}{|c|c|c|c|}
\hline & Scale & Batik practitioner & Non-batik practitioner \\
\hline High & 8 & $\begin{array}{l}\text { Able to adjust and maintain the } \\
\text { temperature of the wax }\end{array}$ & $\begin{array}{c}\text { Ability to deliver a variety of complex } \\
\text { design }\end{array}$ \\
\hline$\hat{T}$ & 7 & $\begin{array}{l}\text { Ability to maintain consistency of wax } \\
\text { line thickness }\end{array}$ & Ease of operation \\
\hline & 6 & Ease of operation & $\begin{array}{l}\text { Able to adjust and maintain the } \\
\text { temperature of the wax }\end{array}$ \\
\hline & 5 & $\begin{array}{c}\text { Ability to deliver a variety of complex } \\
\text { design }\end{array}$ & $\begin{array}{c}\text { Ability to maintain consistency of wax } \\
\text { line thickness }\end{array}$ \\
\hline & 4 & Printing speed & Maintenance \\
\hline & 3 & Maintenance & Printing speed \\
\hline & 2 & Cost of equipment & Cost of equipment \\
\hline Low & 1 & Size of $2 \mathrm{D}$ printer & Size of 2D printer \\
\hline
\end{tabular}


Table 5: Overall priority ratings for the batik printer feature with percentage based on survey

\begin{tabular}{|c|c|c|c|}
\hline & Scale & Features & \\
\hline \multirow{2}{*}{ High } & 8 & Ease of operation & \multirow{8}{*}{ Extruder unit } \\
\hline & 7 & Ability to deliver a variety of complex design & \\
\hline \multirow{4}{*}{ 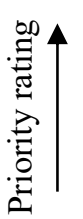 } & 6 & Able to adjust and maintain the temperature of wax & \\
\hline & 5 & Ability to maintain consistency of wax line thickness & \\
\hline & 4 & Printing speed & \\
\hline & 3 & Maintenance & \\
\hline \multirow{2}{*}{ Low } & 2 & Cost of equipment & \\
\hline & 1 & Size of the $2 \mathrm{D}$ printer & \\
\hline
\end{tabular}

The main target market for the batik printer is for both batik and non-batik practitioners such as entrepreneurs, hobbyists, and art faculties in higher academic institutions. Considering the inputs from the non-batik practitioner is essential to avoid myopic product design since the batik practitioners are only represented by a small group of experts [40]. Therefore, despite the differences in preferences, it is necessary to consider a consensus or overall performance rating, as shown in Table 5 to ensure that the new product is attractive and satisfactorily captures the voice of customers in the market segment [40]. The overall results show that both 'ease of operation 'and 'ability to deliver a variety of complex design' share similar percentages at $15.3 \%$ and $15.1 \%$, respectively. The least favorable attribute is the size of the $2 \mathrm{D}$ printer at $6.3 \%$. The priority ratings obtained for the batik printer feature are then integrated into the HOQ matrix.

\subsection{House of Quality}

The number of sections or rooms applied in the HOQ varies from as simple as 4 sections to a more complex matrix with more than 8 sections [41]. Fig. 7 represents the HOQ used in the decision-making process for the development of conceptual designs for the batik printer. In this study, benchmarking and competitive assessment was not conducted for the batik printer. Benchmarking and competitive assessments are commonly deduced from a formal market survey and present the customer's comparative assessment of the new product with those available in the market [42]. Vairaktarakis [43] highlighted that it is crucial that customers can and should only assess products that they use and are accustomed to. However, as batik printers are highly customized products and are not commonly used, competitive assessment based on customer feedback was not performed to avoid faulty judgment. Several HOQ studies have also been performed without benchmarking and competitive assessments $[45,46]$.

The customer's requirements (CR) for a batik printer include printing speed, the ability to adjust and maintain wax temperature, ease of operation, ability to maintain consistency of wax line thickness and quality, ability to deliver a variety of complex designs, equipment costs, 2D printer size, and maintenance (Room 1). The priority ratings in Room 2 were determined by the overall survey results. Based on the survey result, the top three (3) priorities for the batik printer features are ease of operation, ability to deliver complex design, and ability to maintain and control the wax temperature. The engineering specifications (ES) in Room 3 include a temperature controller, heating element, extruder design, interface software, nozzle diameter, motor, printer configuration, printed product dimension, spare parts availability, and cleaning tools. The correlation matrix, i.e., the roof of the house of quality (Room 4), is formed to define the interrelationship between each of the engineering specifications. All the highly rated customer requirements show a strong relationship with the design of extruders on engineering specifications. The relationship 
between engineering specifications and customer requirements in Room 5 reveals that there are two primary engineering specifications: the heating element and the extruder, which are highly linked to various customer requirements.

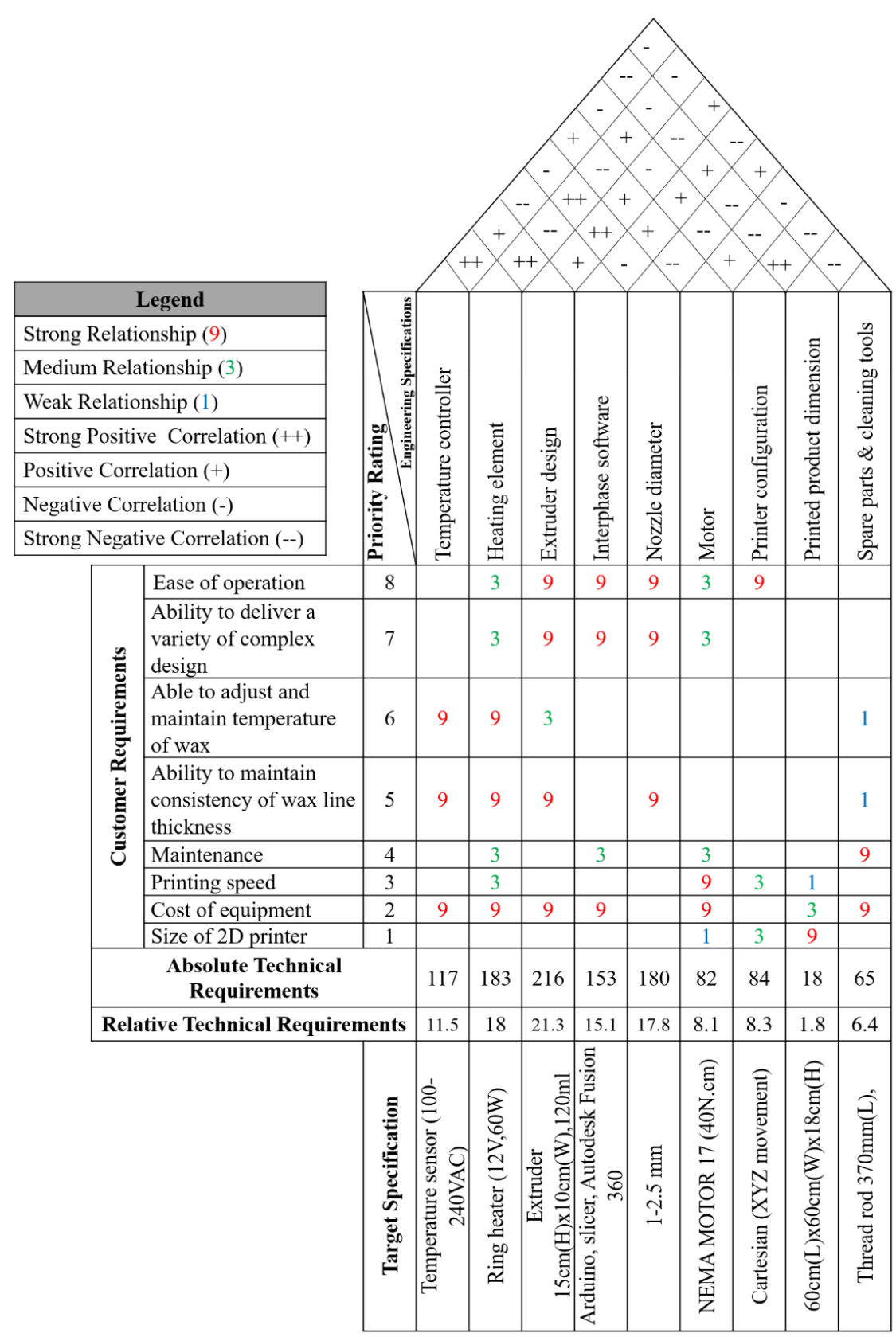

Fig. 7: The HOQ matrix for the batik printer.

Determining the ratings for the HOQ structure is crucial as it aids in developing a product that is marketable and attracts customers [46]. Evaluation on absolute technical requirements in Room 6 indicates that the extruder design (216), the heating element (183), nozzle diameter (180) are the top three (3) engineering elements. The corresponding relative technical requirements in Room 7 are presented in Fig. 8. Based on these absolute and relative assessments in Fig. 8, it is evidenced that the extruder body, heating element, and nozzle diameter which form the extrusion unit are the most critical engineering components for the batik printer. 


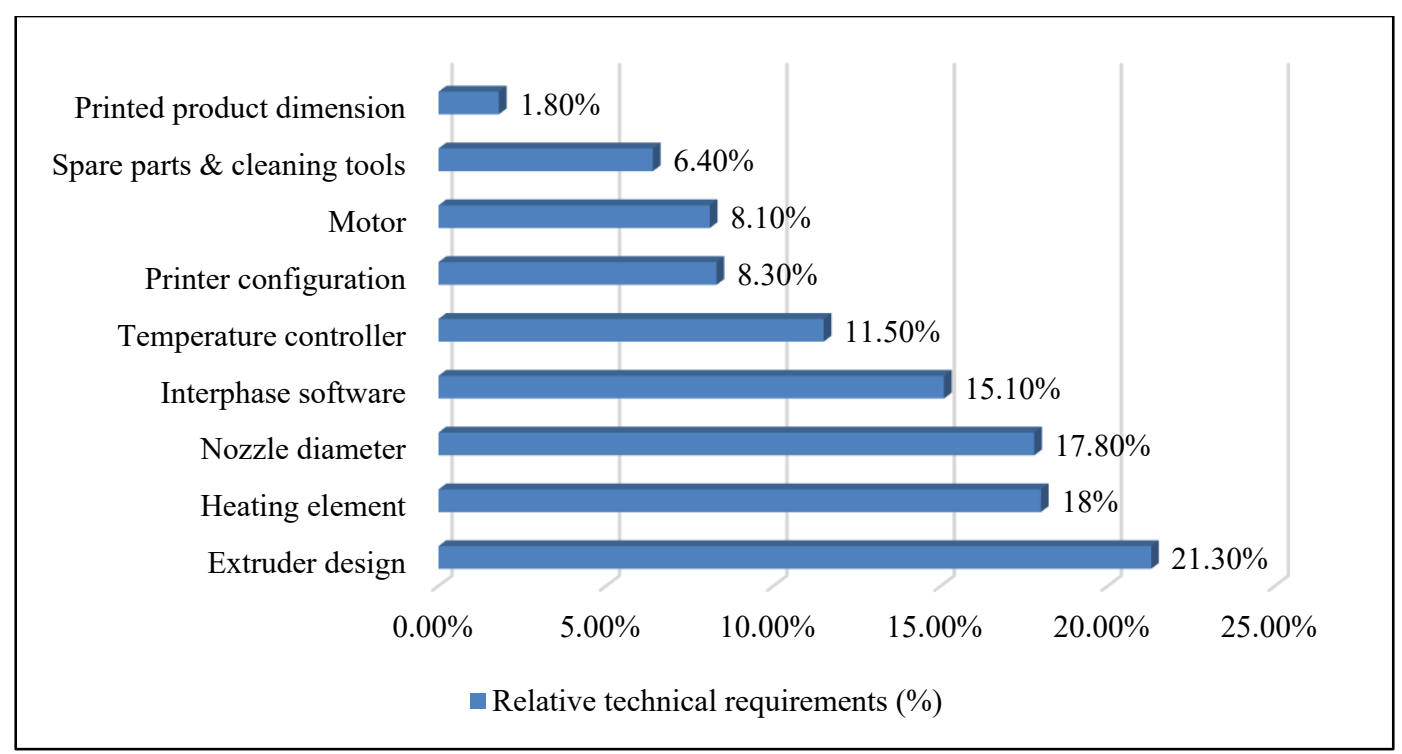

Fig. 8: Relative technical requirements (\%) based on engineering specifications for the batik printer.

\subsection{Conceptual Design of the Batik Extruder and Printer Based on HOQ}

Conceptual design is a key activity in the product development process and significantly affects the accuracy, cost, manufacturability, and life cycle features of the product [47]. In this work, the conceptual design of the extrusion unit (extruder body, heating element, and nozzle diameter) is prioritized and mapped against relevant customer requirements such as ease of operation, adjustment and maintaining of wax temperature, consistency of wax line thickness, and delivery of complex designs (specified in Table 5). A combination table with possible solutions that meet both engineering specifications (i.e., extrusion system) and customer requirements are presented in Table 6 . Possible designs of the extruder body were identified, and concept $\mathrm{C}$ was selected to ease cleaning operation and was further developed into the final concept as shown in Fig. 9. A ceramic ring heater with a feedback thermocouple $(12 \mathrm{~V}, 60 \mathrm{Watt})$ was selected, as the size is compatible with the extruder body and can control the required range of melting temperature for the batik wax $\left(70{ }^{\circ} \mathrm{C}-100\right.$ $\left.{ }^{\circ} \mathrm{C}\right)$. This will ensure the consistency and quality of the wax line rendered on the fabric. The extruder's nozzle diameter was determined by taking into consideration of available tjanting design. The traditional tjanting tool can be categorized into three types based on its function, diameter, and the number of nozzles. Complex designs can be delivered using a modular approach in which the extruder body is interchangeable with the extruder head. Hence the extruder head was designed with (i) a medium-size nozzle diameter of $1 \mathrm{~mm}$ and $2.5 \mathrm{~mm}$ adapted from tjanting rengrengan design and (ii) single and multiple nozzles.

The priority ratings in HOQ highlighted that 'ease of operation' is one of the topmost desirable features for the batik printer. Besides extruder design and nozzle diameter, 'ease of operation' also has a strong relationship with printer configuration and software interface. The structural framework for the batik printer in this study is based on 3D printer configurations. The three common types of configurations for the 3D printer are cartesian, delta, and polar. In this study, a cartesian-based system is adopted as it allows for the left to right movement ( $\mathrm{X}$-axis motion), front to back movement (Y-axis motion), and up and down movement (Z-axis motion). A batik printer having a cartesian configuration provides 'ease of operation' as it is easier to maintain and calibrate. The design is also supported by various hardware resources and can be integrated with various open-sourced software for printing 
path configuration. The three possible conceptual designs for the batik printer are presented in Fig. 10.

Table 6: Combination table based on engineering specifications and customer requirements for the extrusion unit

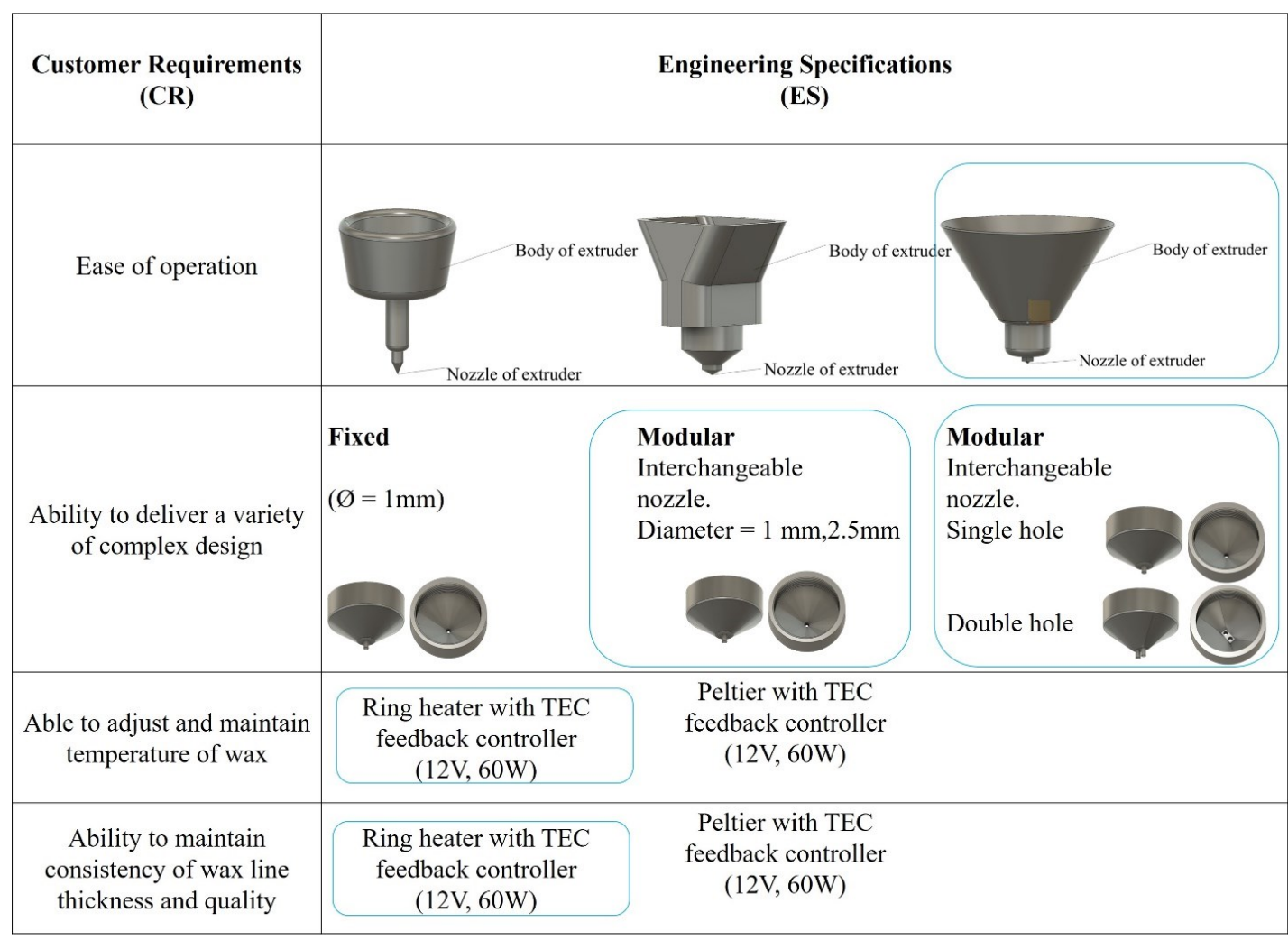

a)

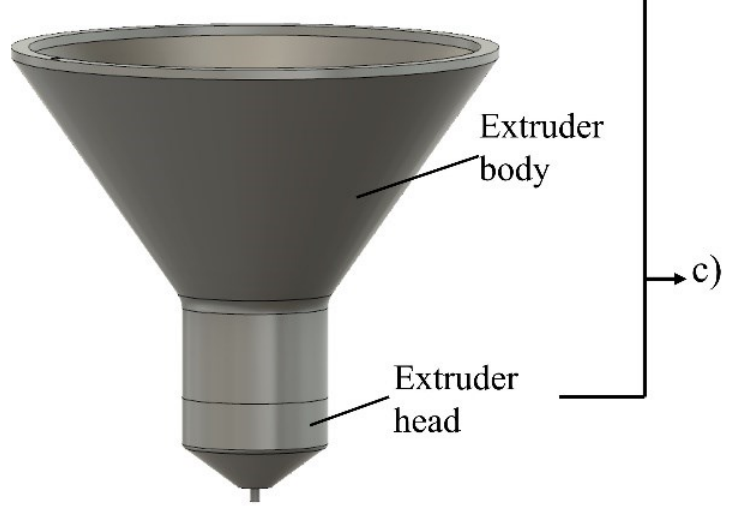

b)

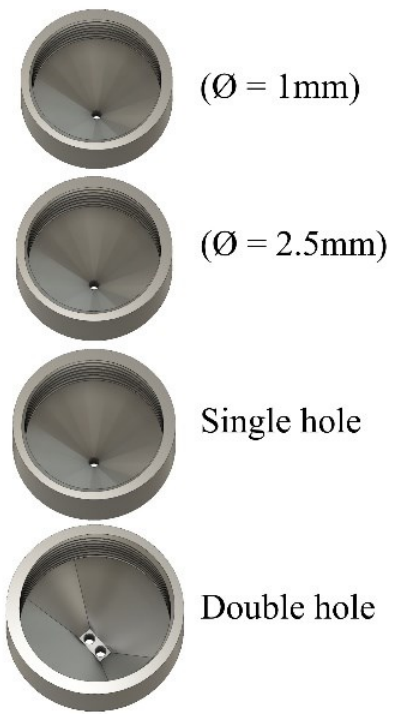

Fig. 9: Modular extruder unit design consisting of (a) extruder body and extruder head assembly, (b) extruder head with different nozzle diameter, (c) extruder head with different nozzle opening. 
a)

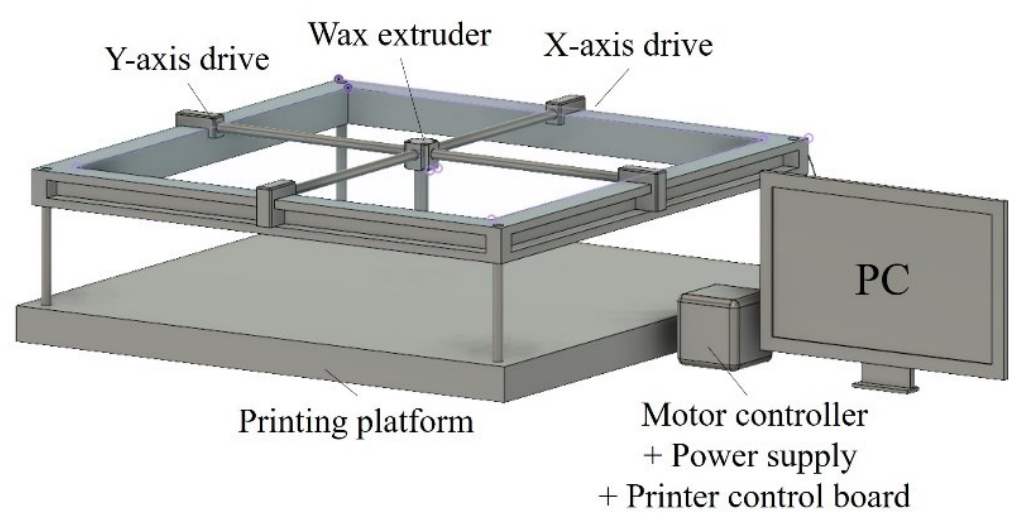

b)

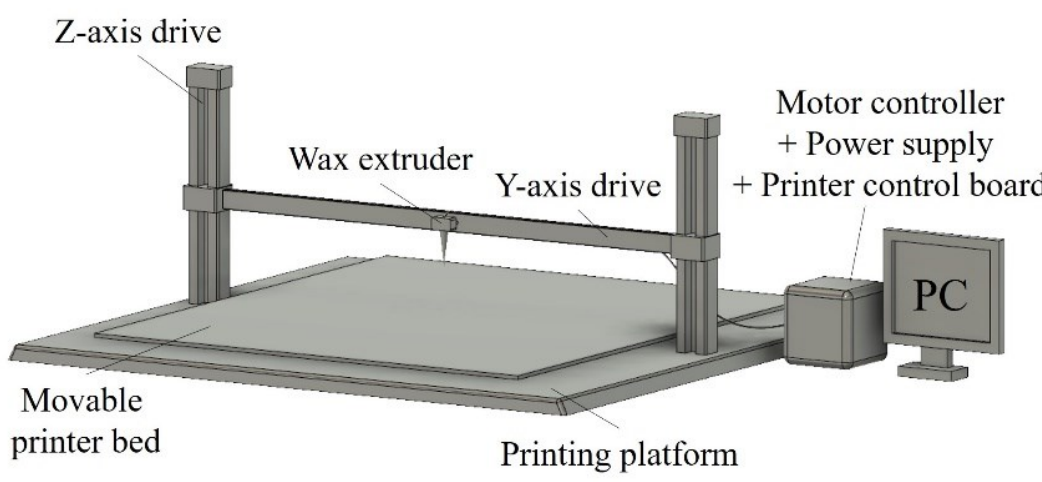

c)

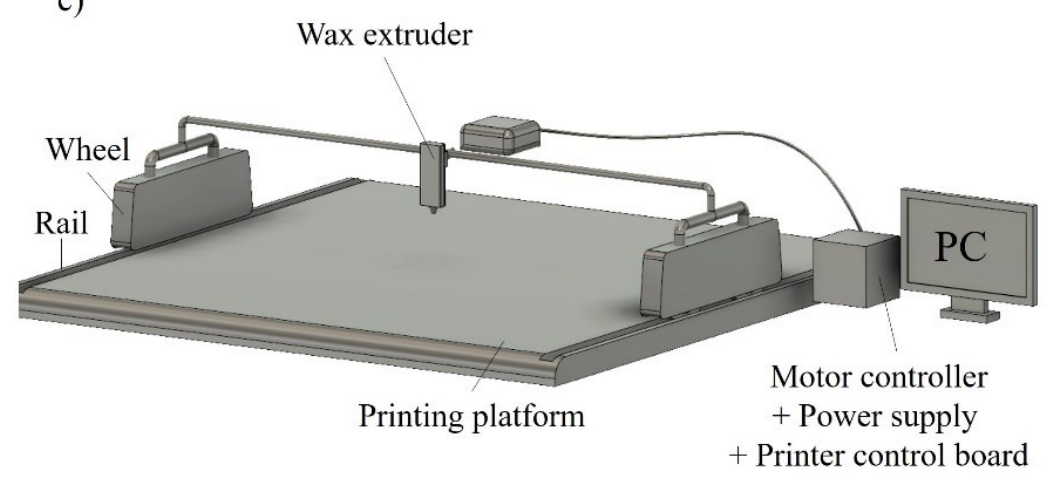

Fig. 10: Cartesian-based conceptual designs (a-c) for the batik printer.

The expiration of various 3D printer patents has partly contributed to the development of an increasing number of open-sourced interface software. The process flow and examples of image generation based on open-sourced software for the batik printer are proposed in Fig. 11. There are 3 main components for any 2D images to be converted into printed images, i.e., image converter, slicer software, and printer interface. Firstly, the format of any 2D images (.jpg, .gif, etc.) based on drawings or illustrations need to be converted into STL format using image converter software (3D Builder, selva3d.com, Ultimaker Cura, imagetostl.com, etc). The STL software is then assessed by the slicer software (Ultimaker Cura, Ideamaker, etc) to create the sequence of G-codes in a program that integrates movement, wax extrusion rate, wax melt temperature, and sensor data. The G-code program is then uploaded into the batik printer and executed using printer interface such as Pronterface. 


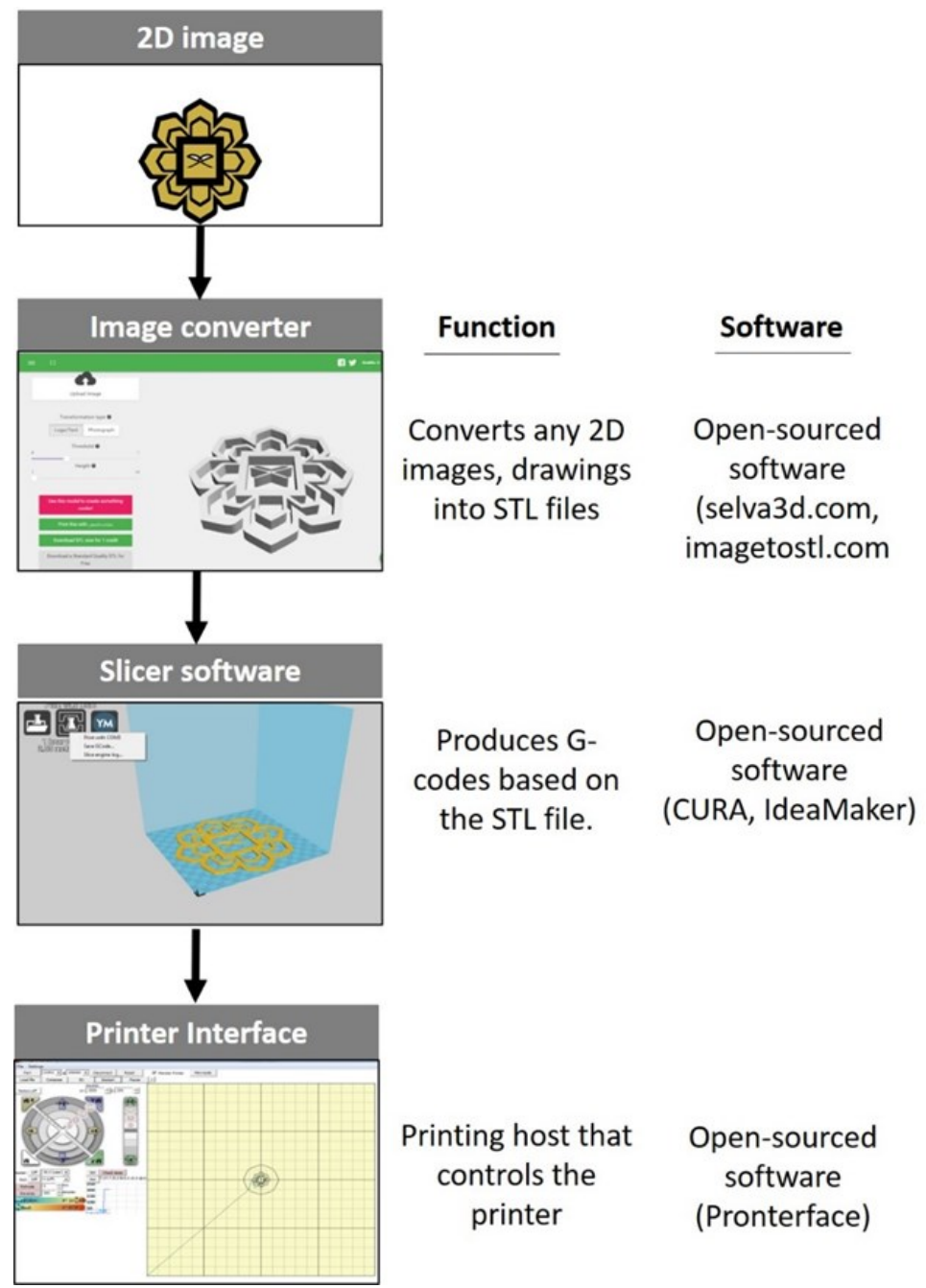

Fig. 11: Process flow for 2D image conversion using open-sourced software for the batik printer.

\section{CONCLUSION}

The house of quality is a vital component that forms the quality functional deployment. The voice of customer (VOC) or customer requirements were translated from survey questionnaires. Results showed that the topmost priority feature for the batik practitioners is 'ability to adjust and maintain the temperature of the wax' whilst the non-batik practitioners responded with 'ability to deliver a variety of complex designs'. The overall voice of customers was considered to ensure that the new product is satisfactory and able to attract a larger market. These voices of customers were integrated into the decision-making process via the house of quality. The absolute and relative assessments performed revealed that the extruder body, heating element, and nozzle diameter which form the extrusion unit were the most critical engineering specified components for the batik printer. The technical requirements of the extrusion unit (extruder body, heating element, and nozzle diameter) were then mapped against relevant customer requirements to aid the design of the extruder system. As a result, a modular-based extruder system operated using a ceramic ring heater (12 V, 60 Watt) with multiple detachable heads was proposed. Since 'ease of operation` is a highly desirable printer feature for the customers, several cartesian-based batik printer configurations were proposed at the end of this study. Further performance assessmentbased study will be conducted with actual integrated software and hardware for the batik printer. 


\section{ACKNOWLEDGEMENT}

This work was fully supported by the International Islamic University Malaysia and funded by the Ministry of Higher Education Malaysia (FRGS/1/2018/TK03/UIAM/02/3). The authors would like to express their deepest gratitude for the technical assessment and input provided by 3D Gens Sdn. Bhd.

\section{REFERENCES}

[1] Redzuan M, Aref F. (2011) Constraints and potentials of handicraft industry in underdeveloped region of Malaysia," Afr. J. Bus. Manag., 5(2): 256-260.

[2] Anon. (2017) The Malaysian Handicraft Annual Report 2017, Kuala Lumpur, Malaysia.

[3] Teng YY. (2018) Making batik her life's purpose. The Star Online. [Online]. Available: https://www.thestar.com.my/metro/focus/2018/12/15/making-batik-her-lifes-purpose

[4] Benzin K. (2016) Batik - an ancient indonesian tradition. Reddduckpost. [Online]. Available: https://www.redduckpost.com/batik-an-ancient-indonesian-tradition/

[5] Musa R, Kyi W, Rampal KG. (2000) Work-related musculoskeletal symptoms among batik workers in Kelantan. Malays. J. Med. Sci., 7(2):13-17.

[6] Yusof N, Yusof R, Ahmat Basri FMF, Soin N. (2013) Ergonomic evaluation of postural assessment among 'canting' batik workers," Adv. Eng. Forum., 10: 226-230.

[7] Rahman AAA, Pillai S. (1996) Mahathir: Leadership and Vision in Science \& Technology. Academy of Sciences Malaysia, Universiti Putra Malaysia Press.

[8] Muthi'ah W. (2018) Study of computerized-batik technique using 'Batik Kelowong' machine in Batik Adelia, Bekasi, IOP Conference Series: Materials Science and Engineering, 453(1): 012022 .

[9] Morris AS, Elamvazuthi I. (1998) Automating the batik colouring process, Part I: An investigation of colouring kinetics on woven fabrics. In UKACC International Conference on Control'98: 1-4 September 1998; Swansea., 1:224-228.

[10] Affanti TB, Hidayat SR. (2018) Batik innovations in Surakarta Indonesia. In 3rd International Conference on Creative Media, Design and Technology: 25 September 2018; Surakarta., pp. $138-141$.

[11] Mohd NH, Shuib NH, Baharin HB. (2019) Industri batik tempatan 'dibunuh. BH Online. [Online].Available:https://www.bharian.com.my/berita/nasional/2019/03/539919/industribatik-tempatan-dibunuh

[12] Ya'kub EM, Wibisono K. (2019) Canting batik elektrik 'made in' Arek Surabaya. Antara News. [Online]. Available: https://www.antaranews.com/berita/156642/canting-batik-elektrik-madein-arek-surabaya

[13] Nair N. (2014) A boost for batik. The Star Online. [Online]. Available: https://www.thestar.com.my/news/community/2014/09/26/a-boost-for-batik-designers-worklifts-profile-of-traditional-fabric

[14] Zakaria R. (2019) Make wearing batik a culture. NST Online. [Online]. Available: https://www.nst.com.my/news/nation/2019/01/451180/make-wearing-batik-culture

[15] National Research Council (2001) Theoretical foundations for decision making in engineering design. National Academy Press.

[16] Wolniak R. (2018) The use of QFD method advantages and limitation. Prod. Eng. Arch., 18:1417.

[17] Wolniak ER, Sędek A. (2009) Using QFD method for the ecological designing of products and services. Qual. Quant., 43(4):695-701.

[18] Park T, Kim KJ. (1998) Determination of an optimal set of design requirements using house of quality. J. Oper. Manag., 16(5): 569-581.

[19] Chang KH. (2014) Design theory and methods using CAD/CAE: The computer aided engineering design series. London, Academic Press.

[20] Dieter GE, Schmidt LC. (2009) Engineering design. Boston, McGraw-Hill Higher Education. 
[21] Li X, Zhao W, Zheng Y, Wang R, Wang C. (2014) Innovative product design based on comprehensive customer requirements of different cognitive levels. Sci. World. J. 2014: 627093.

[22] Leal JE. (2020) AHP-express: A simplified version of the analytical hierarchy process method. MethodsX, 7:100748.

[23] Siswiyanti S, Rusnoto R. (2018) Penerapan ergonomi pada perancangan mesin pewarna batik untuk memperbaiki postur kerja. J. Optimasi Sist. Ind., 17(1):75-85.

[24] Fauziyah F. (2021) The development of Yogyakarta special batik design to meet customer desire and satisfaction using quality function deployment. In Proceedings of the 4th International Conference on Sustainable Innovation 2020-Accounting and Management: 13-14 October 2020; Yogyakarta., pp. 399-405.

[25] Kamal M, Wang Y, Kennon R. (2016) Redesigning cultural product by applying quality function deployment, WIT Trans. Eng. Sci., 113: 413-419.

[26] Adieba MH, Dwiyanto BM. (2016) Analisis peningkatan kualitas produk batik menggunakan pendekatan quality function deployment (QFD) (Studi Kasus Batik BL di Pekalongan). Diponegoro J. Manag., 5(3):198-209.

[27] Rinawati DI, Sari DP, Pujotomo D, Kasih PH. (2018) Natural dyes product design using green quality function deployment II method to support batik sustainable production. In E3S Web of Conferences: January 2018. 73:04014.

[28] Cochran WG. (2007) Sampling techniques. John Wiley \& Sons.

[29] Homkhiew C, Ratanawilai T, Pochana K. (2012) Application of a quality function deployment technique to design and develop furniture products. Songklanakarin J. Sci. Tech., 34(6):663668.

[30] Tavakol M, Dennick R. (2011) Making sense of Cronbach's alpha. Int. J. Med. Educ., 2:53-55.

[31] Bernal L, Dornberger U, Suvelza A, Byrnes T. (2009) Quality function deployment (QFD) for services. International SEPT Program, Leipzig, Germany.

[32] Ramírez Y, Cisternas LA, Kraslawski A. (2017) Application of house of quality in assessment of seawater pretreatment technologies. J. Clean. Prod., 148:223-232.

[33] Hauser JR, Clausing D. (1988) The house of quality. Harv. Bus. Rev., 66:63-73.

[34] Aomar R, Dhanhani J, Ali S. (2013) An enhanced QFD approach for improving water tanks sustainability at a local water distributor. Ind. Eng. Manag., 2(4):54-64.

[35] Park T, Kim KJ. (1998) Determination of an optimal set of design requirements using house of quality. J. Oper. Manag., 16(5): 569-581.

[36] Lee AW, Lin GT, Kuo WH, Lee SJ. (2017) The application of quality function deployment to smartwatches: the house of quality for improved product design. In Portland International Conference on Management of Engineering and Technology: Oregon; 9-13 July 2017., pp. 16.

[37] Aditya F, Agatha YV, Shamsuddin SA, Dhelika R, Aulia DC. (2018) Temperature control of canting with electric heating for batik making. In International Electronics Symposium on Engineering Technology and Applications: 29-30 October 2018; Bali., pp. 48-54.

[38] Poon ST. (2017) The journey to revival: thriving revolutionary batik design and its potential in contemporary lifestyle and fashion. Int. J. Hist. Cult. Stud., 3(1): 48-59.

[39] Büyüközkan G, Ertay T, Kahraman C, Ruan D. (2004) Determining the importance weights for the design requirements in the house of quality using the fuzzy analytic network approach. Int. J. Intell. Syst., 19(5): 443-461.

[40] Vairaktarakis GL. (1999) Optimization tools for design and marketing of new/improved products using the house of quality. J. Oper. Manag., 17(6): 645-663.

[41] Prasad B. (1998) Review of QFD and related deployment techniques. J. Manuf. Syst., 17(3): 221-234.

[42] Griffin A, Hauser JR. (1993) The voice of the customer. Mark. Sci., 12(1): 1-27

[43] Chan LK, Wu ML. (2002) Quality function deployment: a comprehensive review of its concepts and methods. Qual. Eng., 15(1):23-35.

[44] Peters MH, Kethley BR, Bullington K. (2005) Course design using the house of quality, J. Educ. Bus. 80(6): 309-315. 
[45] Isaac OT, Olumide OT, Rasaki OO. (2015) Application of house of quality matrix to material selection for engineering designs, Br. J. Appl. Sci. Technol., 10(4): 1-11.

[46] Prasad KD, Subbaiah KV. (2011) Prioritization of customer needs in house of quality using conjoint analysis. In 5th International Quality Conference: 20 May 2011; Kragujevac., pp. 693699.

[47] Betteridge M, Maropoulos PG. (1995) A review of conceptual design research and industrial practice in concurrent. In Proceedings of the Eleventh National Conference on Manufacturing Research: 12-14 September; Leicester., pp. 693-697. 